\title{
Towards OBE: A Case Study of Course Outcome (CO) and Programme Outcome (PO) Attainment for Product Design and Development Course
}

\author{
Masni-Azian, A. ${ }^{1}$, Rahimah, A.H. ${ }^{1}$ and M.S., Othman ${ }^{1}$ \\ I'Faculty of Manufacturing Engineering, Universiti Teknikal Malaysia Melaka (UTeM), Malaysia)
}

\begin{abstract}
The Outcome Based Education (OBE) has been one of the major concern of most academic institutions in Malaysia, especially among engineering departments since the Engineering Accreditation Council (EAC) has made it compulsory towards programme accreditation. However, various understanding towards the concept of OBE resulted to various attainment to Programme Outcome (PO) based on the Course Outcome $(C O)$. Execution of the OBE may not be an easy matter as the mapping of the CO for each assessment may be mapped to multiple PO. This paper describe the analysis process of the $C O$ and PO attainment for Product Design and Development subject, which is offered to all $2^{\text {nd }}$ year students of Faculty of Manufacturing Engineering, Universiti Teknikal Malaysia Melaka. Two methods are incorporated, (1) direct measurement, and (2) segregated measurement. The study identified that segregated measurement are more sensitive towards identifying the issues which affect attainment of $\mathrm{CO}$ and PO. Issues related to non-fulfilment of either $\mathrm{CO}$ or PO for Product Design and Development subject can be traced to lack of awareness towards product sustainability, synthesizing product design problems and student's attitude towards citing proper literature information throughout the development of their product.
\end{abstract}

Keywords : Outcome Based Education, Course Outcome, Programme Outcome, Engineering Education

\section{INTRODUCTION}

The implementation of Outcome Based Education (OBE) has been among the main focus of academic institution in Malaysia, especially among engineering departments when Malaysia signed in as provisional member of the Washington Accord through the Engineering Accreditation Council (EAC) in 2003 [1]. EAC has made OBE implementation as a compulsory practise in order for the institution to attain accreditation for all cohorts. The implementation of OBE is intended to ensure the curricula design fulfils the programme outcome and programme education objective, which shall reflect the achievement to the university's mission and vision. The concept of $\mathrm{OBE}$ is about developing the curricular structure based on what the learner are expected to achieve at the end of the education programme [2].

The direction towards OBE implementation has been supported by most academic institution which offers engineering courses in Malaysia [3]-[9]. Various education models has been highlighted in support towards OBE implementation [1], [10]. The emphasis of OBE are able to produce the human capital needs as required by the industry based on the feedback obtained from the stakeholders [3]. It was proposed that effective OBE implementation requires the institution to totally replace their curriculum framework and develop new structure that reflects the intended outcome [2]. However, restructuring existing curriculum requires in-depth considerations and a very time consuming process. Added to the fact that the EAC will visit the academic institution on yearly basis, or once every two-years, changing the entire curriculum when four ongoing cohort takes place requires the establishment of a special committee who will not be involved with any teaching and learning, research and innovation, and writing and publication workload. Thus, to start everything from scratch may not be a feasible option among the academic members.

Also, the understanding of OBE itself varies among academic institution [2]. The OBE implementation is often regarded as compliance-driven instead of performance-driven activity. The execution seems very structured on paper, but the implementation may involve daunting data collection process which resulted to lack of commitment among academic members in ensuring the success of OBE implementation. Among the issues pertaining to Programme Education Objective (PEO) and Programme Outcome (PO) may be associated to varying attainment method due to different understandings of course coordinator. There is no common ground of understanding with regard to determining the percentage of achievement. Some may only determine the course achievements based on final exams only, some may only consider selected questions in the assessment, and some other may consider all assessments.

In addition, the execution of OBE may not be an easy matter as the mapping of Course Outcome (CO) to PO may not necessarily be mapped to one item only. One CO may be mapped to multiple PO which resulted to further confusion with regard to the attainment calculations. 
Due to the demanding need of getting the programme accredited and the wide gap in the OBE system, most coordinator tend to tweak the measurement of the $\mathrm{CO}$ to ensure that all achievement is above the predetermined percentage. Thus, real issues to the curricula structure could not be brought forward due to the varying assessment measurement. In addition, it may result to significant differences that affect the actual attainment of the course. Therefore, the aim of this paper is to explore varying methods of measuring $\mathrm{CO}$ attainment which reflect the PO achievement.

\section{CO-PO MAPPING}

Programme Outcomes for the Faculty of Manufacturing Engineering, Universiti Teknikal Malaysia Melaka (UTeM) are mainly adopted from EAC Manual which are consulted and agreed with the stakeholders, including the appointed industrial advisory panel. The list of PO emphasizes the expectations for students of Bachelor of Manufacturing Engineering upon their graduation (TABLE 1).

Table 1. Programme Outcomes of

Faculty of Manufacturing Engineering, UTeM

\begin{tabular}{|c|c|}
\hline PO 1 & $\begin{array}{l}\text { Ability to apply basic knowledge of sciences, engineering and } \\
\text { technology in their profession. }\end{array}$ \\
\hline PO 2 & $\begin{array}{l}\text { Ability to design, develops, implement and maintain } \\
\text { manufacturing systems. }\end{array}$ \\
\hline PO 3 & $\begin{array}{l}\text { Ability to analyse problems and synthesis solutions in } \\
\text { manufacturing engineering. }\end{array}$ \\
\hline PO 4 & $\begin{array}{l}\text { Ability to communicate effectively with both engineers and } \\
\text { society. }\end{array}$ \\
\hline PO 5 & Understand engineering ethics and social responsibilities. \\
\hline PO 6 & $\begin{array}{l}\text { Ability to utilise a system approach to design and evaluate } \\
\text { operational performance. }\end{array}$ \\
\hline PO 7 & In-depth technical competence in manufacturin \\
\hline PO 8 & $\begin{array}{l}\text { Ability to function effectively as an individual or in multi- } \\
\text { disciplinary and multi-cultural teams. }\end{array}$ \\
\hline PO 9 & $\begin{array}{l}\text { Ability to design and conduct experiments as well as to } \\
\text { analyse and interpret data. }\end{array}$ \\
\hline PO 10 & $\begin{array}{l}\text { Ability to understand the principles of sustainability in design } \\
\text { and development. }\end{array}$ \\
\hline PO 11 & $\begin{array}{l}\text { e-long } \\
\text { ip. }\end{array}$ \\
\hline
\end{tabular}

The Faculty has predetermined the PO that needs to be mapped with the offered courses to ensure all POs are addressed. For Product Design and Development (PDD) subject Semester 2 2011/2012, the PO that needs to be addressed is $\mathrm{PO} 2, \mathrm{PO}, \mathrm{PO} 4, \mathrm{PO} 8, \mathrm{PO} 10$ and $\mathrm{PO} 11$. The subject coordinator has structured the course outcome (CO) with respect to appropriate assessment method as per the predetermined PO (TABLE 2).

Assessment for the subject includes Group Assignments, Tests and Product Design Project. The project includes presentations, project folder, poster presentation, prototype and project report. At the end of the semester, the students are expected to develop and fabricate the prototype and exhibit it within campus community. Their workmanship will be assessed by panel of juries from various backgrounds. Attainment for each CO and PO predetermined by the faculty are $60 \%$ of the overall students must achieve $50 \%$ and above from the full mark.

192 detail assessment data out of 241 students enrolled in this subject are successfully collected. Data analysis became even more complex as each assessment is being mapped to different $\mathrm{CO}$ and multiple $\mathrm{PO}$ (TABLE 3). For example, under assignment 1 and 2, CO4 does not necessarily being mapped to all PO2, PO3 and PO10 as shown in general overview from TABLE 2.

Due to various understanding with regard to the $\mathrm{CO}$ and $\mathrm{PO}$ attainment, the achievement for each $\mathrm{CO}$ and PO are measured using two techniques, which is (1) direct measurement, and (2) segregated measurement. Direct measurement assumes that a single CO attainment reflects to the entire PO mapped to it. On the other hand, segregated measurement assumes that $\mathrm{CO}$ and PO to be treated as individual and segregated component. 
Table 2. General Overview of PO and CO for

Product Design and Development subject

\begin{tabular}{|c|c|c|c|c|c|c|}
\hline Course Outcome (CO) & PO2 & PO3 & PO4 & PO8 & PO10 & PO11 \\
\hline $\begin{array}{l}\text { CO1 } \\
\text { Able to describe the principles of product } \\
\text { design and development. }\end{array}$ & & $x$ & & & & \\
\hline $\begin{array}{l}\mathrm{CO} 2 \\
\text { Able to apply design principles in product } \\
\text { design and development. }\end{array}$ & 0 & 0 & 0 & 0 & 0 & 0 \\
\hline $\begin{array}{l}\mathrm{CO} 3 \\
\text { Able to demonstrate ability to develop } \\
\text { prototype. }\end{array}$ & & & 0 & & & \\
\hline $\begin{array}{l}\mathrm{CO} 4 \\
\text { Able to synthesis problem and solutions in } \\
\text { design process. }\end{array}$ & $\diamond$ & $\diamond$ & & & $\diamond$ & \\
\hline & $\begin{array}{l}\text { Indic } \\
\mathbf{x} \\
0\end{array}$ & $\begin{array}{l}\text { Ass } \\
\text { Tes } \\
\text { Proj }\end{array}$ & & & & \\
\hline
\end{tabular}

Table 3. Mapping of Assessments to CO and PO

\begin{tabular}{|c|c|c|c|c|c|c|c|}
\hline COs & Assessments & PO2 & PO3 & PO4 & PO8 & PO10 & PO11 \\
\hline \multirow[t]{2}{*}{ CO1 } & $\begin{array}{l}\text { Test } 1 \\
3 \text { Questions }\end{array}$ & & $x$ & & & & \\
\hline & $\begin{array}{l}\text { Test } 2 \\
3 \text { Questions }\end{array}$ & & $x$ & & & & \\
\hline \multirow{2}{*}{$\begin{array}{l}\mathrm{CO2} \\
\mathrm{CO3} \\
\end{array}$} & Project Folder & $x$ & $x$ & $x$ & $x$ & & $x$ \\
\hline & Project Report & $x$ & $x$ & $x$ & $x$ & $x$ & \\
\hline \multirow[t]{2}{*}{ CO4 } & $\begin{array}{l}\text { Assignment } 1 \\
\text { Case study } \\
4 \text { Questions }\end{array}$ & X & X & & & $x$ & \\
\hline & $\begin{array}{l}\text { Assignment } 2 \\
\text { Patent search } \\
2 \text { Questions }\end{array}$ & & X & & & & \\
\hline
\end{tabular}

\section{OPTION 1: DIRECT MEASUREMENT}

The measurements of PO are based on the mapping of $\mathrm{CO}$ and PO as per TABLE 2 with the assumption that each $\mathrm{CO}$ corresponds directly to respective PO. The illustration of the mapping is shown in FIGURE 1. The Deputy Dean of Academic will decide the mapping of PO as per the institution's Education Objectives, which reflect to its mission and vision. Prior to discussions, head of departments will then map the pre-determined PO to departmental subjects, and finally, the subject coordinator shall construct the CO based on the predetermined PO.

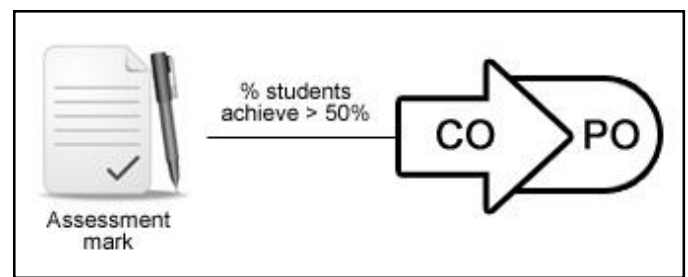

Figure 1. Direct measurement

Percentages of achievement are purely based on the overall marks attained by the students as shown in equation (1).

$$
A=\frac{n}{N} \times 100 \%
$$

with $A: \mathrm{CO}$ or $\mathrm{PO}$ achievement

$n$ : Total students achieve $50 \%$ above

$N$ : Total students 
TABLE 4 exhibit the CO-PO achievement of Product Design and Development subject based on direct measurement method. It is observed that the set of data used for the assessment for respective $\mathrm{CO}$ will be repetitively used for other PO as well. For example, achievement for CO4 is based on Assignment 2. The percentage of student achievement $(80.2 \%)$ will result to the achievement of the entire PO mapped to CO4, which are PO2, PO3 and PO10. Attainment for all CO and PO are observed to exceed $60 \%$ of the overall students. The outcome of this method implies that attainment of $\mathrm{CO}$ will reflect the attainment of PO.

Table 4. CO-PO achievement based on direct measurement

\begin{tabular}{|c|c|c|c|c|c|c|c|c|}
\hline \multirow{2}{*}{ COs } & \multirow{2}{*}{ Assessments } & \multicolumn{6}{|c|}{ PO Achievement (\%) } & \multirow{2}{*}{$\begin{array}{l}\text { Total CO } \\
(\%)\end{array}$} \\
\hline & & PO2 & PO3 & PO4 & PO8 & PO10 & PO11 & \\
\hline \multirow[t]{2}{*}{ CO1 } & Test 1 & & 93.2 & & & & & 93.2 \\
\hline & Test 2 & & 69.8 & & & & & 69.8 \\
\hline $\mathrm{CO2}$ & Project & 83.3 & 83.3 & 83.3 & 83.3 & 83.3 & 83.3 & \multirow{2}{*}{83.3} \\
\hline $\mathrm{CO3}$ & Project & & & 83.3 & & & & \\
\hline \multirow[t]{2}{*}{$\mathrm{CO4}$} & Assignment 1 & 69.3 & 69.3 & & & 69.3 & & \multirow{2}{*}{74.8} \\
\hline & Assignment 2 & 80.2 & 80.2 & & & 80.2 & & \\
\hline & Total PO (\%) & 77.6 & 79.2 & 83.3 & 83.3 & 77.6 & 83.3 & \\
\hline
\end{tabular}

\section{OPTION 2: SEGREGATED MEASUREMENT}

As the assessment of $\mathrm{CO}$ may be mapped to multiple $\mathrm{PO}$, there is a probability that the component of a particular assessment will also be mapped to different PO. Thus, it may be more viable to measure the CO and PO achievement in segregated manner (FIGURE 2).

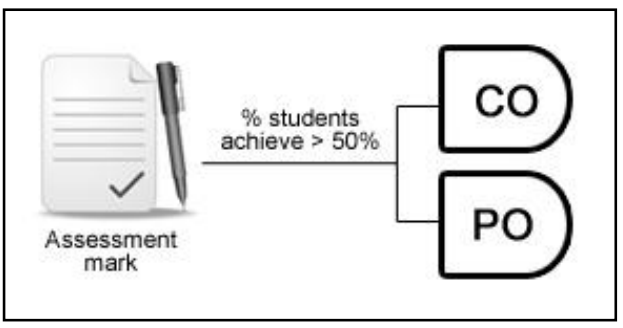

Figure 2. Segregated measurement

Taking Assignment 1 as an example, the assessment consists of four (4) questions, and the mapping of each question is as below:

- Question $1 \rightarrow \mathrm{CO} 4$, and PO 3

- Question $2 \rightarrow \mathrm{CO} 4$, and PO 10

- Question $3 \rightarrow \mathrm{CO} 4$, and PO 3

- Question $4 \rightarrow \mathrm{CO} 4$, and PO 2

Unlike previous method, the achievement to respective $\mathrm{CO}$ may not necessarily translate the achievement of the entire PO mapped to it. This approach requires the subject coordinator to design their assessment, which corresponds to the structured $\mathrm{CO}$, and they will also have to consider the mapping of each question to PO as well. Thus, the achievement measurement may be calculated in a segregated manner as per equation (2) and (3) below.

$$
\begin{aligned}
& A_{C O}=\frac{n_{C O}}{N} \times 100 \% \\
& A_{P O}=\frac{n_{P O}}{N} \times 100 \%
\end{aligned}
$$

with $A_{C O}:$ CO achievement

$A_{P O}:$ PO achievement

$n_{C O}:$ Total students achieve $\mathrm{CO}>60 \%$

$n_{P O}:$ Total students achieve PO $>60 \%$

$N$ : Total students 
IOSR Journal of Research \& Method in Education (IOSR-JRME)

e-ISSN: 2320-7388, p-ISSN: 2320-737X. Volume 4, Issue 2 Ver. III (Mar-Apr. 2014), PP 55-61 www.iosrjournals.org

TABLE 5 exhibits the CO-PO attainment based on segregated method. It was observed that wide range of data may be collected and problematic areas may be easily identified. However, this option involves wide series of data collection, which may result to extensive data management. The task of organising such data may be very daunting and tedious if it is not controlled properly. Nonetheless, this option is able extract vital information with regard to students' performance and specific issues may be tackled for continuous improvement.

Table 5. CO-PO attainment based on segregated measurement

\begin{tabular}{|c|c|c|c|c|c|c|c|c|}
\hline \multirow{2}{*}{ COs } & \multirow{2}{*}{ Assessments } & \multicolumn{6}{|c|}{ PO Achievement (\%) } & \multirow{2}{*}{$\begin{array}{l}\text { Total } \\
\text { CO }(\%)\end{array}$} \\
\hline & & PO2 & PO3 & PO4 & PO8 & PO10 & PO11 & \\
\hline \multirow[t]{2}{*}{$\mathrm{CO1}$} & $\begin{array}{l}\text { Test 1 } \\
\text { Question 1 } \\
\text { Question 2 } \\
\text { Question 3 }\end{array}$ & & $\begin{array}{l}79.7 \\
96.4 \\
76.0\end{array}$ & & & & & \multirow{2}{*}{72.8} \\
\hline & $\begin{array}{l}\text { Test 2 } \\
\text { Question 1 } \\
\text { Question 2 } \\
\text { Question 3 }\end{array}$ & & $\begin{array}{c}77.6 \\
* 34.4 \\
72.4\end{array}$ & & & & & \\
\hline \multirow[t]{2}{*}{$\mathrm{CO2}$} & $\begin{array}{l}\text { Project Folder } \\
\text { Proposal } \\
\text { Quality } \\
\text { Drawing } \\
\text { Selection } \\
\end{array}$ & 82.3 & & $\begin{array}{l}89.1 \\
69.8\end{array}$ & & & 79.2 & \multirow[b]{2}{*}{72.3} \\
\hline & $\begin{array}{l}\text { Project Report } \\
\text { Format } \\
\text { Intro } \\
\text { Literature } \\
\text { Method } \\
\text { Result } \\
\text { Conclusion } \\
\text { Reference } \\
\end{array}$ & 64.1 & 83.3 & $\begin{array}{l}77.1 \\
88.5\end{array}$ & 63.5 & \multicolumn{2}{|l|}{$* 37.0$} & \\
\hline \multirow[t]{2}{*}{$\overline{\mathrm{CO3}}$} & $\begin{array}{l}\text { Project Folder } \\
\text { CTPS } \\
\text { Idea } \\
\text { L/ship } \\
\text { Entrepreneur } \\
\text { Discussions } \\
\text { Planning } \\
\text { Survey }\end{array}$ & 75.5 & $\begin{array}{l}97.9 \\
94.8\end{array}$ & 84.4 & $\begin{array}{l}96.3 \\
85.9\end{array}$ & & 84.9 & \multirow[t]{2}{*}{87.6} \\
\hline & $\begin{array}{l}\text { Project Report } \\
\text { Attitude }\end{array}$ & & & 81.3 & & & & \\
\hline \multirow[t]{3}{*}{$\mathrm{CO4}$} & $\begin{array}{l}\text { Assignment } 1 \\
\text { Question } 1 \\
\text { Question } 2 \\
\text { Question 3 } \\
\text { Question } 4\end{array}$ & 67.2 & $\begin{array}{l}* 23.1 \\
83.9\end{array}$ & & & $* 54.7$ & & \multirow[t]{2}{*}{61.9} \\
\hline & $\begin{array}{l}\text { Assignment } 2 \\
\text { Question 1 } \\
\text { Question 2 }\end{array}$ & & $\begin{array}{c}90.1 \\
* 52.1 \\
\end{array}$ & & & & & \\
\hline & Total PO (\%) & 72.3 & 74.0 & 81.7 & 81.9 & $* 51.1$ & 82.1 & \\
\hline
\end{tabular}


Attainment for all CO is observed to exceed $60 \%$ while the attainment for PO shows that only PO10 falls below the $60 \%$ limit. Based on this finding, improvement shall be made in highlighting sustainability in design and development process. The outcome of this method implies that attainment of CO may not necessarily reflect the attainment of $\mathrm{PO}$.

\section{CO-PO ATTAINMENT}

The comparison of $\mathrm{CO}$ and $\mathrm{PO}$ attainment between the two options incorporated above is shown in FIGURE 3 and FIGURE 4. Based on FIGURE 3, attainment for all CO using both methods is observed to exceed $60 \%$ of the limit. Using the segregated method, it was observed that CO4 is just above the passing limit. Thus, subject coordinator may further improve the subject performance by focusing on problem synthesis and encouraging students to be more proactive towards suggesting creative solution in design process.

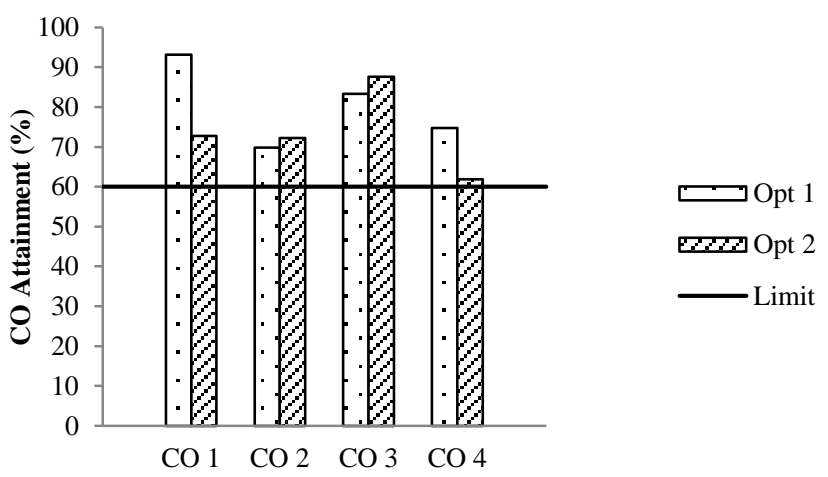

Figure 3. Comparison of $\mathrm{CO}$ achievement

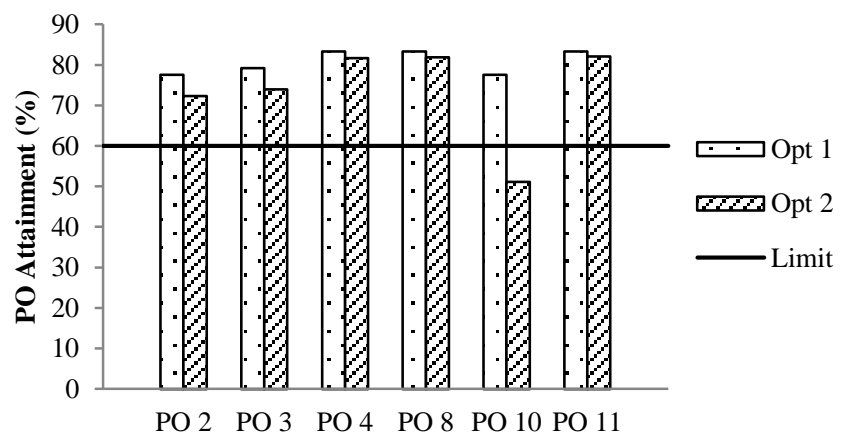

Figure 4. Comparison of PO achievement

Based on FIGURE 4, PO attainment using direct method shows all PO achieved the 60\% limit. However, segregated method highlighted that PO10 falls below the 60\% limit. Referring to TABLE 5, the low attainment is contributed by poor interpretation to sustainability, which is measured, from Assignment's case study and Project Literature. Upon further investigation, the low achievement in Literature also highlighted the issue of students' attitude towards constructing proper literature citations.

\section{CONCLUSION}

The OBE implementation of CO and PO attainment has been explored for Product Design and Development subject that were offered to all undergraduates of Faculty of Manufacturing, UTeM. Two methods have been incorporated which is direct method and segregated method. The direct method implies that the $\mathrm{CO}$ attainment directly reflects the PO attainment. On the other hand, the segregated method implies each individual component in the assessment is mapped to its respective $\mathrm{CO}$ and $\mathrm{PO}$ and shall be assessed in segregated manner. $\mathrm{CO}-\mathrm{PO}$ attainment incorporating direct measurement and segregated measurement exhibit varying result. The segregated method is more sensitive towards identifying the issues, which affect attainment of CO and PO. 
Issues related to non-fulfilment of either $\mathrm{CO}$ and $\mathrm{PO}$ can be traced to awareness towards product sustainability, problem synthesizing and student's attitude towards citing proper literature information throughout the development of their product. Continuous improvement may be implemented by focusing on the issues at hand. However, managing extensive data using segregated method may be time consuming and deters the commitment of academic members towards effective OBE implementation.

Subject coordinator holds a big responsibility of designing the subject curricular that can ease the attainment analysis process. All assessments to be implemented in the course (eg. Assignment, Test, Project, Final Exam) should be prepared before the beginning of the semester. This is achievable if the subject coordinator has been involved in the same subject for at least one teaching semester since they would have adequate insight on preparing the teaching plan and the $\mathrm{CO}$ as per the predetermined $\mathrm{PEO}$ and PO.

In addition, the institution should develop a system that provides standardised $\mathrm{CO}-\mathrm{PO}$ attainment analysis. The system should consider the constraints among academic members who are directly involved with data collection and data management activity. The system interface should be easily navigated as it plays a significant role towards encouraging the commitment of academic members. Data transfer activity should be developed as practical as one can be to avoid redundant process.

Finally, the effectiveness of OBE implementation goes back to the practise of the related academic members. They have to be proactive in managing the data on time so that the activity would not be too overwhelming at the end of the semester. Proper planning will definitely lead to fruitful result with less hassle in managing the extra requirement by the accreditation body.

\section{References}

[1] M.M.Noor, K.Kadirgama, M.M.Rahman, M.R.M.Rajab, R. A.Bakar, and I. Abdullah, "Education Reform Model at Faculty of Mechanical Engineering, Universiti Malaysia Pahang," in International Journal Conference in Recent Trends in Mechanical Engineering (IJCRTME09), 2009.

[2] S. M. Ali Askar, "Implementation of OBE in Engineering Education: Are we there yet?," in International Conference on Engineering Education (ICEED), 2009, pp. 164-166.

[3] A. M. Zaiton, A. H. Norihan, and H. Nurmala Irdawaty, "Emphasizing OBE in UTeM subjects to develop human capital," in International Conference on Engineering Education (ICEED), 2009, pp. 173-176.

[4] Z. Abidin, N. Omar, H. Hashim, M. Fuad, A. Latip, and M. M. Othman, "Outcome Based Education Performance Evaluation on Electrical Engineering Laboratory Module,” in International Conference on Engineering Education (ICEED), 2009, pp. 153-158.

[5] A. Anuar, N. H. Shuaib, K. Salleh, M. Sahari, and I. Z. Abidin, "Continual Improvement and Assessment Plan for Mechanical Engineering Programme in UNITEN," in International Conference on Engineering Education (ICEED), 2009 , pp. 19-24.

[6] M. Jaafar, N. Nordin, R. Wagiran, M. J. M. M. N. A. Aziz, M. R. Osman, J. Noozaei, and F. N. A. Abdulaziz, “Assessment Strategy for an Outcome Based Education," in International Conference on Computing in Civil and Building Engineering, 2010.

[7] A. A. Mutalib, R. A. A. Rahmat, A. K. A. Rashid, F. Suja, and S. Sahril, "Measurement and Evaluation of Program Outcomes in the Civil Engineering Courses," Procedia - Soc. Behav. Sci., vol. 60, no. 0, pp. 333-342, Oct. 2012.

[8] I. Z. Abidin, A. Anuar, and N. H. Shuaib, "Assessing the attainment of course outcome (CO) for an engineering course," in 2 nd International Conference of Teaching and Learning (ICTL 2009), 2009, pp. 1-7.

[9] U. Anisa, U. Amirulddin, M. Osman, and F. A. Hamid, "Analysis of Programme Outcomes Achievement for Electrical Engineering Programmes in UNITEN," in International Conference on Engineering Education (ICEED), 2009, pp. $148-152$.

[10] A. A. Aziz, M. J. M. M. Noor, A. A. A. Ali, and M. S. Jaafar, “A Malaysian Outcome-Based Engineering Education Model,” Int. J. Eng. Technol., vol. 2, no. 1, pp. 14-21, 2005. 